\title{
Paper Dosing Unit
}

National Cancer Institute

\section{Source}

National Cancer Institute. Paper Dosing Unit. NCI Thesaurus. Code C82484.

A dosing unit equal to the amount of active ing redient(s) contained in a piece of paper. 